\title{
Altered Protein Kinase C Activation Associated with Rat Embryonic Dysmorphogenesis
}

\author{
MATTIAS GÄRESKOG AND PARRI WENTZEL
}

Department of Medical Cell Biology, Uppsala University, SE-751 23 Uppsala, Sweden

\begin{abstract}
It has been suggested that protein kinase $\mathrm{C}(\mathrm{PKC})$ is involved in the etiology of diabetic complications. The aim of the present study was to investigate the putative involvement of different PKC isoforms ( $\alpha, \beta 1, \beta 2, \gamma, \delta, \epsilon$, and $\zeta)$ in the embryopathy of diabetic rat pregnancy. Embryos were collected from normal and diabetic rats and assayed for PKC activity, PKC mRNA levels, and PKC protein distribution on gestational d 10 and 11. Embryos of diabetic rats showed markers of increased activity of PKC- $\alpha$, PKC- $\beta 1$, PKC- $\gamma$, PKC- $\delta$, and PKC- $\zeta$ compared with embryos of normal rats on $\mathrm{d} 10$. In addition, the malformed embryos had further increased PKC- $\gamma$, and PKC- $\delta$ activity markers compared with nonmalformed embryos of diabetic rats on gestational d 10. In contrast, maternal diabetes caused only two alterations in PKC activity markers on gestational d 11, i.e. both PKC- $\alpha$ and PKC- $\zeta$ were decreased in embryos of diabetic rats. We found increased mRNA levels of PKC- $\beta 1$ and PKC- $\zeta$ on $d$
\end{abstract}

\section{ABSTRACT}

10 in embryos of diabetic rats and decreased mRNA levels of PKC- $\gamma$ on d 11 in embryos of diabetic rats. Malformed embryos from diabetic rats showed increased distribution of PKC- $\beta 1$ and $\mathrm{PKC}-\beta 2$ protein in the tissue compared with nonmalformed embryos from diabetic rats and embryos from normal rats. We conclude that diabetic rat embryopathy may be associated with increased activity and enhanced tissue distribution of several PKC isoforms in early organogenesis. (Pediatr Res 56: 849-857, 2004)
DAG, diacylglycerol

\section{Abbreviations}
G6PDH, glucose-6-phosphate dehydrogenase
GAPDH, glyceraldehyde phosphate dehydrogenase
PKC, protein kinase $\mathrm{C}$

Maternal diabetes is associated with an increased risk of several complications in the offspring, such as growth disturbances and congenital malformations (1-4). The malformation rate in the infants of diabetic mothers is 6-9\% (5-7) compared with $2-3 \%$ (2) in infants of nondiabetic mothers. Development of the heart, kidney, and CNS is often affected (1,8-11). The mechanism behind diabetic embryopathy and other diabetic complications, such as retinopathy, nephropathy, and neuropathy, is not known. However, analogous etiological mechanisms have been suggested for the three latter diabetic complications $(12,13)$, mechanisms that may also play a role in diabetic embryopathy. Factors and processes that have been suggested to cause diabetic complications may therefore be investigated for their putative capacity to induce embryonic malformations. In addition, identifying the teratological factors in diabetic pregnancy may advance the understanding of all diabetic complications.

Received August 19, 2003; accepted July 7, 2004.

Correspondence: Mattias Gäreskog, Ph.D., Department of Medical Cell Biology, Uppsala University, Biomedical Center, P.O. Box 571, SE-751 23 Uppsala, Sweden; e-mail: Mattias.Gareskog@medcellbiol.uu.se

Supported by the Ernfors Family Fund, the Swedish Diabetes Association, the Novo Nordisk Foundation, and the Swedish Medical Research Council (grant nos. 12X-7475 and 12X-109).

DOI: 10.1203/01.PDR.0000145295.88601.B9
Several proposals have emerged to explain the origin of the diabetic embryopathy. Previous studies have suggested that increased glucose levels lead to malformations (14-17). In addition, oxidative stress $(18,19)$, disturbances in the polyol pathway (20-22), and prostaglandin metabolism (23-26) have been proposed to induce diabetic embryopathy.

It has been suggested that enhanced activity of PKC may be a common feature of all diabetic complications $(12,13)$. In support of this notion, culture of bovine endothelial cells in high glucose concentration induces increased PKC activity (27). However, a recent study has reported decreased PKC activity in Schwannoma cells cultured in high glucose concentration (28), suggesting decreased activity of PKC as a factor in developing neuropathy, at least in some cell types.

Embryonic development and maldevelopment with respect to PKC activity have also been investigated. In a study of diabetic embryopathy in a mouse model it was reported that increased activity of PKC was correlated with congenital malformations (29). Other studies have shown, however, that inhibition of PKC activity in rodent embryos may cause malformations $(30,31)$, indicating that basal PKC activity is necessary for normal embryonic development. Evidently, clarifying the role of PKC in the etiology of diabetic embryopathy necessitates further investigation. 
PKC belongs to serine/threonine kinases and participates in a variety of signal transduction pathways that affect many cellular processes such as proliferation, differentiation, and programmed cell death (32). These pathways are important for the development of the embryo and several isoforms have been identified in embryonic tissues $(\alpha, \beta, \gamma, \delta, \epsilon, \eta, \theta, \mu, \lambda, \zeta)$ $(33,34)$. Altered PKC activity may therefore perturb embryonic development (30). The activation of PKC entails a translocation of the enzymatic protein from the cytosol (inactive form) to the membrane (active form) (35), a process reported for several PKC isoforms, e.g. PKC- $\alpha$ (36-38), PKC- $\beta$ (36-38), PKC- $\gamma(37)$, PKC- $\delta$ (37-39), PKC- $\epsilon(40)$, PKC- $\zeta(41)$, and $\mathrm{PKC}-\eta$ (38). In this work, we used the Western blot-estimated amount of membrane-bound PKC protein normalized to total protein content as a marker for enzyme activity of each PKC isoform (42-44). In addition, we used the ratio of immunoreactive membrane-bound PKC protein to immunoreactive cytosolic PKC protein as a measure of the extent of membrane translocation of PKC isoenzyme within each experimental group. Furthermore, we examined the mRNA levels and protein distribution of the PKC isoforms in embryos of normal and diabetic rats on gestational d 10 and 11. In particular, we compared markers of enzyme activity and protein distribution between malformed and nonmalformed embryos of diabetic rats and found differences for some isoenzymes, which are displayed below.

The aim was to characterize a possible association between altered PKC activity and disturbed embryonic development in a diabetic environment. We therefore chose to study the time interval of neural tube closure and heart formation (roughly corresponding to gestational $\mathrm{d} 9-11$ in the rat) inasmuch as the embryonic development of the nervous and cardiovascular systems is often severely affected by a diabetic milieu (10).

\section{MATERIALS AND METHODS}

\section{Animals}

Embryos were obtained from normal and diabetic females of a local outbred Sprague-Dawley strain (about 10 pregnancies of each type) with an increased incidence of congenital malformations in diabetic pregnancy $(45,46)$. All rats were fed a commercial pellet diet (AB Analycen, Lidköping, Sweden). The rats had free access to food and tap water and were maintained at an ambient temperature of $22^{\circ} \mathrm{C}$ with a 12-h light/dark cycle. Female and male rats were caged overnight and a positive vaginal smear the following morning designated gestational d 0.

Diabetes was induced with a single injection of $40 \mathrm{mg} / \mathrm{kg}$ streptozotocin (Sigma Chemical Co--Aldrich Chemie, Stenheim, Germany) into a tail vein. Blood glucose was measured after 1 wk with a Glucose Analyzer 2 (Beckman Coulter, Inc., Fullerton, CA). Rats with a glucose concentration exceeding 20 $\mathrm{mM}$ were considered to be diabetic (D). After establishing the diabetic status, mating of the $\mathrm{D}$ females commenced.

On gestational d 10 and 11, the normal and diabetic rats were killed by cervical dislocation. Days 10 and 11 were chosen because these days allowed study of embryogenesis both in vitro and in vivo. The uterus was dissected out. Each embryo was carefully freed of their deciduas and membranes and transferred to a new Petri dish containing PBS.

The Animal Ethical Committee of the Medical Faculty of Uppsala University approved the research protocol including all experimental procedures involving animals.

\section{Estimation of PKC Activity Markers (Western Blot)}

Fractionation of embryonic cells. The embryos were washed in PBS before they were lysed with a Kontes Pellet Pestle motor hand homogenizer in buffer $(20 \mathrm{mM}$ Tris-Hcl, $\mathrm{pH}$ 7.5, $0.25 \mathrm{M}$ sucrose, $5 \mathrm{mM}$ EDTA, $0.2 \%$ Triton, $10 \mathrm{mM}$ Benzamidine, $50 \mathrm{mM} \beta$-mercaptoethanol, $1 \mathrm{mM}$ phenyl methyl sulfonyl fluoride). The homogenized sample was allowed to lysate for 5-10 min. Then $20 \mu \mathrm{L}$ of the lysed sample was drawn and stored for protein determination before spinning down cell debris and nuclei. A cold Beckman rotor was loaded with the supernatant transferred to centrifuge tubes. The samples were spun at $160,000 \mathrm{~g}$ for $20 \mathrm{~min}$ in a Beckman Airfuge (Beckman Coulter, Inc.). The supernatant (cytosolic fraction) was transferred to clean tubes and stored on ice. The pellet (membrane fraction) was resuspended in $30 \mu \mathrm{L}$ loading buffer. The cytosolic fraction was precipitated with 3 volumes of acetone. The precipitated proteins were centrifuged for 10 min in the cold environment. The acetone was poured out and the pellet was suspended in $30 \mu \mathrm{L}$ loading buffer. The samples were heated to $100^{\circ} \mathrm{C}$ for $2-3 \mathrm{~min}$ before they were applied at a $5 \%$ stacking gel with a $7 \%$ running gel. Next, $25 \mu \mathrm{L}$ of each sample was added to the wells and Full Range Rainbow (Amersham Pharmacia Biotech UK, Ltd., Little Chalfont, Buckinghamshire, UK) was used as a marker. The gel was run with $14 \mathrm{~mA}$ for $1 \mathrm{~h}$. After electrophoresis the gel was put in Western blot buffer for 10-15 min. Protran nitrocellulosemembrane (Schleicher \& Shuell, Dassel, Germany) was used for the transfer that proceeded overnight at $30 \mathrm{~V}$.

Immunoblot analysis. The membranes were pretreated with nonfat dry milk to block nonspecific binding (50 mL $1 \times$ PBS, $2.5 \mathrm{~g}$ milk powder, $100 \mu \mathrm{L} 10 \% \mathrm{NaN}_{3}, 100 \mu \mathrm{L}$ Tween) for $1 \mathrm{~h}$. Primary antibody (Santa Cruz Biotechnology, Santa Cruz, CA) was diluted in block buffer, $25 \mu \mathrm{L}$ to $25 \mathrm{~mL}$. Membranes were rinsed for $1.5 \mathrm{~h}$ on a shake board and washed with PBS-Tween $2 \times 10 \mathrm{~min}$. They were then incubated with the secondary antibody (anti-rabbit Ig, Amersham Pharmacia Biotech UK, Ltd.) diluted 1:1000 in $25 \mathrm{~mL}$ of PBS-Tween $+2.5 \%$ BSA (Bayer Corporation, Elkhart, IN).

Two milliliters of solution A and $50 \mu \mathrm{L}$ of solution B (ECL + Western blotting detection system, RPN 2132, Amersham Pharmacia Biotech UK, Ltd.) were mixed in a centrifuge tube and were applied drop-wise on the membrane. After $5 \mathrm{~min}$, the fluid was removed with a Whatman paper. The membranes were confined in plastic film, with the proteins upward, and placed in an exposure box. Film (Hyperfilm MP, $18 \times 24 \mathrm{~cm}$, Amersham Pharmacia Biotech UK, Ltd.) was applied in a darkroom and was exposed for $1 \mathrm{~min}$. Another film was applied, but this time exposed for $4 \mathrm{~min}$. The film was developed with Agfa Curix 60.

The developed film was scanned to a computer and evaluated densitometrically with Kodak Digital Science 1D, ex- 
pressed in arbitrary units (AU). The densitometric measurement of the membrane and cytosolic fractions of each sample was normalized by division of the protein content of the whole sample and the resulting ratio, expressed as AU per microgram, was used as a measure of total PKC isoenzyme content. The membrane-bound fraction (divided with protein content) was subsequently used as a marker of isoenzyme activity (42-44). When the isoenzyme activity differed between malformed and nonmalformed $\mathrm{D}$ embryos (no malformed $\mathrm{N}$ embryos were found), these activities were separately displayed (Fig. 1, $d$ and e). The ratio between membrane-bound and cytosolic PKC protein was calculated as a measure of the extent of membrane translocation of PKC isoenzyme within each experimental group.

Measurement of protein. Total protein content was estimated in each sample from an aliquot of $20 \mu \mathrm{L}$ lysate by the method of Lowry et al. (47) using BSA as standard.

\section{Real-Time PCR Measurement of PKC Expression}

Preparation of total RNA. Total RNA from embryos was isolated with RNeasy mini kit (QIAGEN AG, Basel, Switzer- land) according to the manufacturer's description. Briefly, embryos from normal and diabetic rats were lysed in $350 \mu \mathrm{L}$ buffer. We did not distinguish between embryos with normal and abnormal morphology. Next, $350 \mu \mathrm{L}$ of $70 \%$ ethanol was added to the homogenates and the samples were mixed and applied to RNeasy mini spin columns, which were located in 2 -mL collection tubes. The columns and tubes were centrifuged for $1 \mathrm{~min}$ at 13,000 rpm, the flow-through was discarded, and the columns were washed with $350 \mu \mathrm{L}$ wash buffer (RW1) and spun at 13,000 rpm for $1 \mathrm{~min}$. The samples were DNase treated with $10 \mu \mathrm{L}$ DNase I and $70 \mu \mathrm{L}$ buffer (RDD) and incubated at room temperature for $25 \mathrm{~min}$. Thereafter the columns were washed with $350 \mu \mathrm{L}$ wash buffer (RWI) and spun at 13,000 rpm for $1 \mathrm{~min}$. The columns were subsequently washed with $500 \mu \mathrm{L}$ buffer (RPE) twice, the flow-through discarded after each centrifugation. The columns were transferred to new collection tubes and $50 \mu \mathrm{L}$ RNase-free water was applied to each column twice, and the accumulated flowthrough was collected after the centrifugation (total RNA sample). Then, $1 \mu \mathrm{L}$ of RNase inhibitor was added to each sample (RNA guard, Amersham Pharmacia Biotech UK, Ltd.).
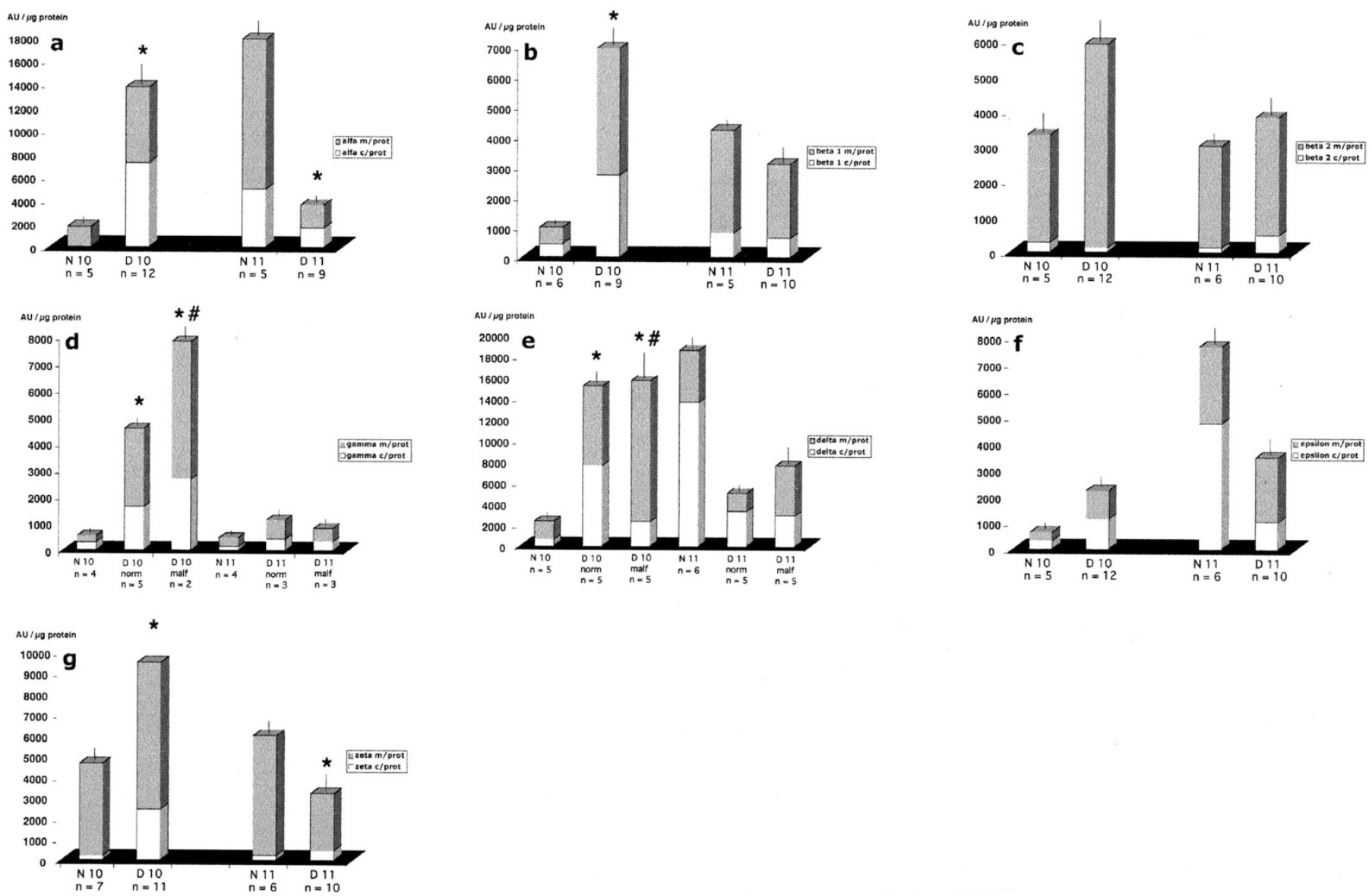

Figure 1. Markers of PKC activity in embryos. Amount of PKC isoenzyme protein in d-10 and d-11 embryos from normal (N) or diabetic (D) rats, estimated by Western blot of membrane (gray portion of bar) and cytosolic (white portion of bar) fractions of whole embryo homogenates. Each fraction is normalized by dividing the densitometric reading (arbitrary unit, $\mathrm{AU}$ ) with the protein content of the whole sample $(\mu \mathrm{g})$, thereby expressing the isoenzyme amount in AU/ $\mathrm{g}$. The normalized amount of membrane-bound PKC isoenzyme protein is regarded as a marker of the enzyme activity of this PKC isoenzyme, shown as the gray portion of each bar. When we detected a difference between nonmalformed and malformed D embryos, both categories are displayed in the figure (denoted " $\mathrm{D}$ 10/11 norm" and "D 10/11 malf," respectively). The PKC isoforms analyzed were PKC- $\alpha(a)$, PKC- $\beta 1(b)$, PKC- $\beta 2(c)$, PKC- $\gamma(d)$, PKC- $\delta(e)$, PKC- $\epsilon(f)$, and PKC- $\zeta(g)$. The embryos were analyzed individually or pooled two-by-two. Significances (ANOVA) of isoenzyme activity: * $p<0.05 v s$ embryos of same age; \#p $<0.05$ vs D normal embryos of same age (d 10 or d 11). 
Preparation of cDNA. One microgram of total RNA was used for reverse transcription. First-strand cDNA synthesis used first-strand beads (Ready To Go, Amersham Pharmacia Biotech AB, Uppsala, Sweden), according to the manufacturer's description. Then $30 \mu \mathrm{L}$ RNase-free water containing 1 $\mu \mathrm{L}$ RNA was heated at $65^{\circ} \mathrm{C}$ for $10 \mathrm{~min}$, then chilled on ice for 2 min. RNA solution was transferred to the First-Strand Reaction Mix Beads and the chosen primer was Oligo (dT). After incubation at $37^{\circ} \mathrm{C}$ for $60 \mathrm{~min}$, the samples were heated to $95^{\circ} \mathrm{C}$ for $5 \mathrm{~min}$. The resulting cDNA was diluted 3 -fold with diethylpyrocarbonate-treated water.

Analysis of PKC mRNA levels. One microliter of the cDNA purified from embryos containing $10 \mathrm{ng}$ of converted total RNA was amplified and measured with real-time PCR using the LightCycler (Roche Diagnostics GmbH, Mannheim, Germany). Specific primers were made by CyberGene AB (Huddinge, Sweden) (Table 1) for PKC. According to the Light Cycler protocol, $1 \mu \mathrm{L}$ of the cDNA was amplified in a final volume of $10 \mu \mathrm{L}$ containing $6.2 \mu \mathrm{L}$ RNase-free water, $1 \mu \mathrm{L}$ FastStart DNA Master SYBR Green I (Roche Molecular Biochemicals, Mannheim, Germany), $2 \mathrm{mM} \mathrm{MgCl}$, and $0.5 \mu \mathrm{M}$ of the sense and antisense primers. For relative quantification, G6PDH was used as control (TIB Molbiol, Berlin, Germany) (Table 1). The Light Cycler Run version 5.32 program was used with following parameters: 1) denaturation at $95^{\circ} \mathrm{C}$ for 10 min, and 2) amplification with a total of 45 cycles with each cycle with denaturation temperature at $95^{\circ} \mathrm{C}$ for $15 \mathrm{~s}$, annealing temperature at $60^{\circ} \mathrm{C}$ for $10 \mathrm{~s}$, and elongation temperature at $72^{\circ} \mathrm{C}$ for $15 \mathrm{~s}$.

Controls were included in each run of the real-time PCR assay. For each primer pair one sample with no cDNA (containing only RNAse-free water) was included. Furthermore, to exclude the possibility of remaining DNA fragments in the samples, $10 \mathrm{ng}$ of the total RNA of each sample was amplified in the Light Cycler. We found no PCR product in the water or in the total RNA samples. We excluded the essential AMV-RT enzyme in the cDNA preparation and found that no PCR product could be amplified.
In a separate pilot study, we compared the expression of G6PDH, actin, and ribosomal protein S-28 in embryos of normal and diabetic rats, and found G6PDH to yield the most stable expression (data not shown).

Results were analyzed for each sample with relative quantification comparing the difference between sample and control crossing point $(\mathrm{Cp})$ values. To render a true value for mRNA levels the calculated difference were transformed according to the formula

$$
2^{-(\text {Cpsample - CpG6 PDH })}
$$

to yield the ratio $\mathrm{PKC}$ isoform/G6PDH.

\section{Immunostaining of embryos}

Embryos were fixed in $4 \%$ paraformaldehyde for $24 \mathrm{~h}$ and stored in $70 \%$ ethanol before they were embedded in paraffin. The embedded embryos were sliced in 5- $\mu \mathrm{M}$-thick sections and put on glass slides overnight.

The slides were deparaffinized, rehydrated, and rinsed in PBS. The sections were covered with $100 \mu \mathrm{L}$ trypsin diluted in $0.1 \% \mathrm{CaCl}_{2}$ for $10 \mathrm{~min}$. Thereafter, the sections were washed with PBS for 10 min and subjected to $100 \mu \mathrm{L} 1 \% \mathrm{H}_{2} \mathrm{O}_{2}$ for 10 $\mathrm{min}$. The slides were rinsed with PBS for $10 \mathrm{~min}$ and subjected to $100 \mu \mathrm{L}$ normal goat serum (Vector Laboratories, Burlingame, CA) for $30 \mathrm{~min}$. We removed the goat serum and added either $100 \mu \mathrm{L}$ primary antibody PKC- $\beta 1 / \beta 2$ (Santa Cruz Biotechnology) or $100 \mu \mathrm{L}$ blocking peptide (Santa Cruz Biotechnology) plus antibody PKC- $\beta 1 / \beta 2$ before incubation overnight (Fig. $4, f-j$; Fig. 5, $f-j$ ).

Slides were washed in PBS for $10 \mathrm{~min}$ and incubated with secondary antibody (Dako EnVision+ Peroxidase, rabbit, ready to use) for $30 \mathrm{~min}$. The slides were washed for $10 \mathrm{~min}$ and then developed with Fast 3,3'-diaminobenzidine tablet sets (Sigma Chemical Co.-Aldrich Chemie, Stenheim, Germany) for $5 \mathrm{~min}$. Finally, the slides were mounted with coverslips.

Table 1. $P C R$ primers

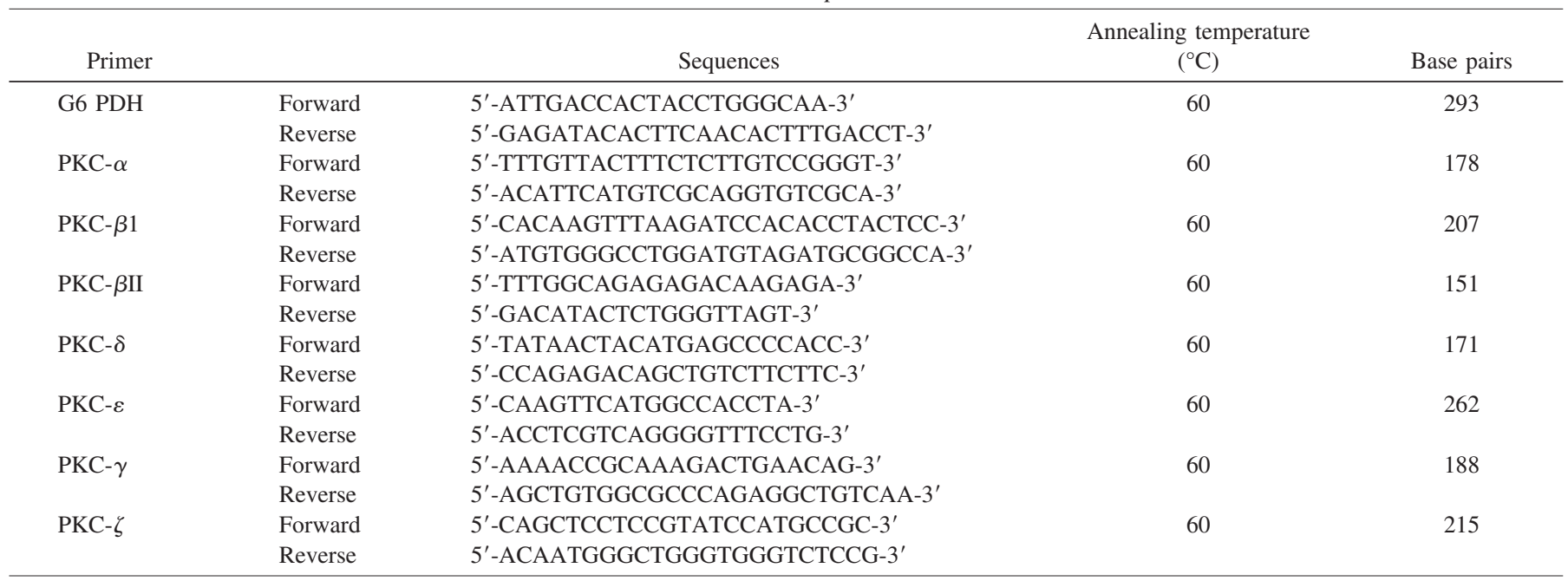




\section{Statistical Considerations}

Statistical significance was determined by ANOVA. In the case of significance $(p<0.05)$, individual groups were compared according to Fisher's protected least significant difference posthoc test. Analyses were performed using the program StatView for Macintosh (SAS Institute, Cary, NC).

\section{RESULTS}

Altered markers of PKC activity. The activity of each PKC isoform was analyzed by Western blot for membrane (m) and cytosolic (c) associated fractions, normalized with protein content. The membrane-bound fraction (divided with protein content) was then used as a marker of isoenzyme activity (42-44). When the isoenzyme activity differed between malformed and nonmalformed $\mathrm{D}$ embryos (no malformed $\mathrm{N}$ embryos were found), these activities were separately displayed (e.g. Fig. $1, d$ and $e$ ). The $\mathrm{m} / \mathrm{c}$ ratio was calculated as a measure of the extent of membrane translocation of PKC isoenzyme within each experimental group (Fig. 2).

PKC- $\alpha$ showed increased activity in d-10 embryos from diabetic rats (D10) compared with embryos of control rats (N10). We found the opposite on gestational d 11, where D11 embryos had lower PKC- $\alpha$ activity than N11 embryos (Fig. 1a).

PKC- $\beta 1$ showed increased activity on gestational d 10 in D10 embryos compared with N10 embryos, whereas PKC- $\beta 1$ activity did not differ between N11 and D11 embryos (Fig. 1b).

PKC- $\beta 2$ showed no differences between $\mathrm{N}$ and D embryos, neither on d 10 nor on d 11 (Fig. 1c).

The malformed D10 embryos (D10 malf) had higher PKC- $\gamma$ activity than the nonmalformed D10 embryos (D10 norm) and both had higher PKC- $\gamma$ activity than the N10 embryos. No such changes were found on gestational d 11 (Fig. 1d). The intensity of the staining of the PKC- $\gamma$ bands was weaker and the bands were more difficult to detect than the stained bands of the other PKC isoforms.

The malformed D10 embryos (D10 malf) had higher PKC- $\delta$ activity than the nonmalformed D10 embryos (D10 norm), which, in turn, was higher than the PKC- $\delta$ activity in the $\mathrm{N} 10$ embryos (Fig. $1 e$ ). On d $11, \mathrm{PKC}-\delta$ activity did not differ between the different groups of embryos. The intensity of the PKC- $\delta$ band was strong in all groups (Fig. 2e).

There were no differences in PKC- $\epsilon$ activity between the groups, either on d 10 or d 11 (Fig. $1 f$ ).
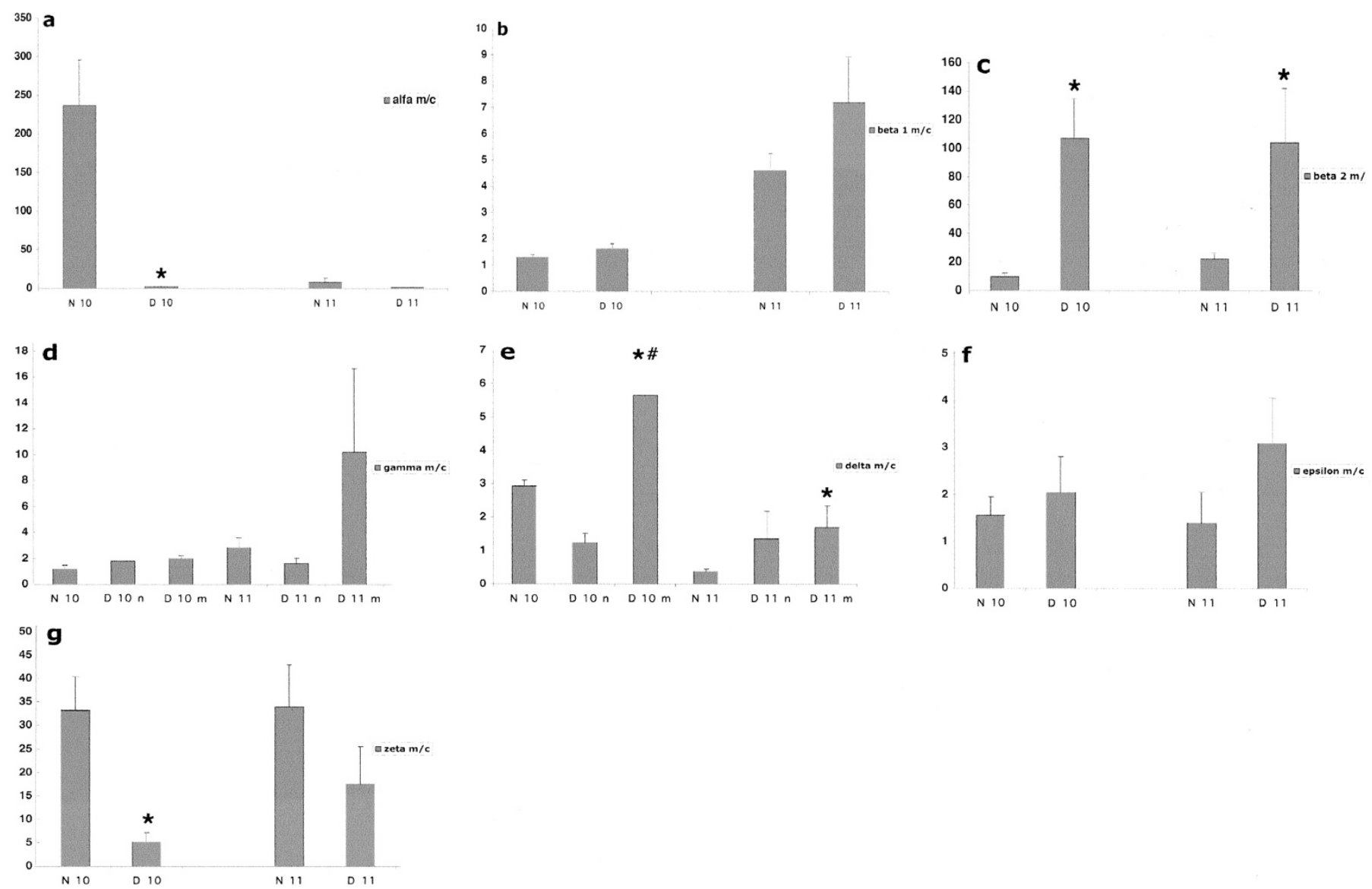

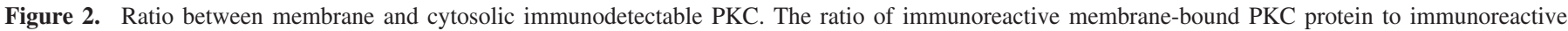

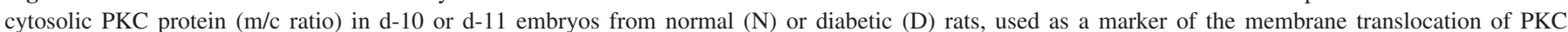

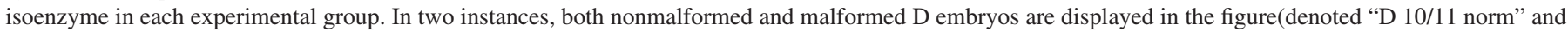

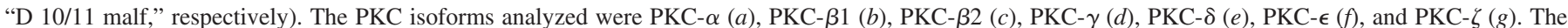

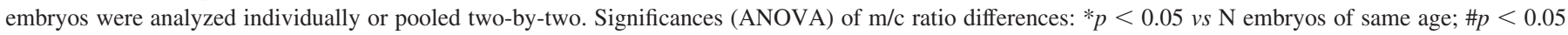
vs $\mathrm{D}$ normal embryos of same age (d 10 or d 11). 
The D10 embryos showed increased PKC- $\zeta$ activity compared with N10 embryos, whereas the D11 embryos had decreased PKC- $\zeta$ activity compared with N11 embryo (Fig. $1 g$ ). The intensity of the PKC- $\zeta$ band was markedly strong in embryos on both d 10 and d 11 .

Estimation of PKC isoenzyme translocation. The $\mathrm{m} / \mathrm{c}$ ratio of PKC- $\alpha$ in the D10 embryos was markedly decreased compared with the $\mathrm{m} / \mathrm{c}$ ratio of the $\mathrm{N} 10$ embryos, whereas the levels in the N11 and D11 embryos showed the same trend, but were more comparable (Fig. $2 a$ ). The $\mathrm{m} / \mathrm{c}$ ratios of PKC- $\beta 1 \mathrm{did}$ not differ between $\mathrm{N}$ and $\mathrm{D}$ embryos in the two age groups (Fig. $2 b$ ). In contrast, the $\mathrm{m} / \mathrm{c}$ ratio of PKC- $\beta 2$ was markedly higher in $\mathrm{D}$ embryos compared with $\mathrm{N}$ embryos both on $\mathrm{d} 10$ and $\mathrm{d} 11$. The $\mathrm{m} / \mathrm{c}$ ratios of PKC- $\gamma$ did not differ between the $\mathrm{d} 10$ and $\mathrm{d} 11$. The $\mathrm{m} / \mathrm{c}$ ratio of PKC- $\delta$ in the malformed D10 embryos was increased compared with both $\mathrm{N} 10$ and D10 normal embryos. In addition, the $\mathrm{m} / \mathrm{c}$ ratio of PKC- $\delta$ in D11 malformed embryos was increased compared with $\mathrm{N} 11 \mathrm{em}-$ bryos (Fig. 2e). There were no differences in PKC- $\epsilon \mathrm{m} / \mathrm{c}$ ratio between the groups, either on d 10 or d 11 (Fig. 2f). With regard to PKC- $\zeta$, the D10 embryos showed a decreased $\mathrm{m} / \mathrm{c}$ ratio compared with the $\mathrm{m} / \mathrm{c}$ ratio of the $\mathrm{N} 10$ embryos, and the $\mathrm{N}$ and D embryos on d 11 showed the same trend (Fig. $2 g$ ).

Measurement of PKC mRNA levels. The mRNA levels of PKC isoforms were investigated by real-time PCR.
The mRNA levels of PKC- $\alpha$ did not differ between N10 and D10 nor between N11 and D11 embryos (Fig. 3a). We found higher mRNA levels of PKC- $\beta 1$ in D10 compared with N10 embryos. The mRNA levels of PKC- $\beta 1$ did not differ between N11 and D11 embryos (Fig. $3 b$ ). PKC- $\beta 2$ mRNA levels did not differ between N10 and D10 nor between N11 and D11 embryos (Fig. 3c). PKC- $\gamma$ mRNA levels did not differ between N10 and D10 embryos. The mRNA level of PKC- $\gamma$ in D11 embryos was lower than in $\mathrm{N} 11$ embryos (Fig. $3 d$ ). PKC- $\delta$ mRNA levels did not differ between the groups on gestational d 10 and 11 (Fig. 3e). PKC- $\epsilon$ mRNA levels did not differ between the groups on gestational d 10 and 11 (Fig. 3f). We found a higher mRNA level of PKC- $\zeta$ in D10 than in N10 embryos but no differences in mRNA levels on gestational d 11 (Fig. $3 g$ ).

$P K C$ protein distribution in embryonic tissues. We investigated distribution and abundance of the PKC isoforms in embryos from $\mathrm{N}$ and $\mathrm{D}$ rats on gestational $\mathrm{d} 10$ and 11 and found no differences between the groups with regard to PKC- $\alpha$, PKC $-\gamma$, PKC- $\delta$, PKC- $\epsilon$, and PKC- $\zeta$ (data not shown). In contrast, we found enhanced accumulation of PKC- $\beta 1$ and $-\beta 2$ proteins in the neural tube, heart, and facial tissues. We found no differences between $\mathrm{N}$ and $\mathrm{D}$ normal embryos; however, in D malformed embryos we found intensified staining for both PKC- $\beta 1$ and - $\beta 2$ compared with the $\mathrm{N}$ and D normal embryos
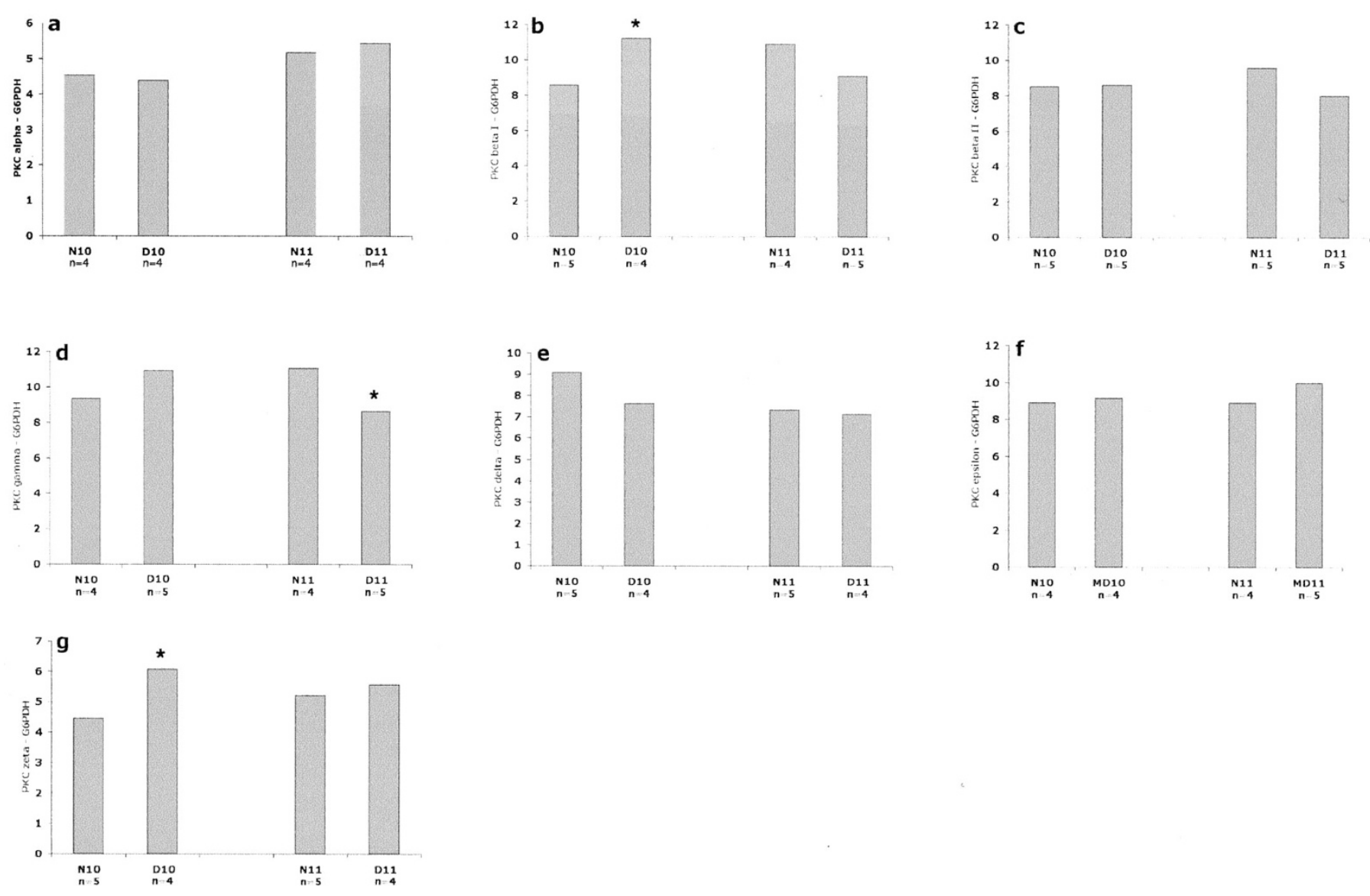

Figure 3. mRNA levels of PKC isoenzymes. Levels of mRNA of different PKC isoforms in d-10 or d-11 embryos from normal (N) or diabetic (D) rats, displayed as the ratio between estimated amount of mRNA of the particular PKC isoform and the amount of mRNA of the house-keeping gene, G6PDH (calculations given in "Materials and Methods"). The isoforms analyzed were PKC- $\alpha(a)$, PKC- $\beta 1(b)$, PKC- $\beta 2(c)$, PKC- $\gamma(d)$, PKC- $\delta(e)$, PKC- $\epsilon(f)$, PKC- $\zeta$ $(g)$. The embryos were analyzed individually. Data are given as mean. Significances (ANOVA): $* p<0.05 v s \mathrm{~N}$ embryo of same age (d 10 or $\mathrm{d} 11$ ). 

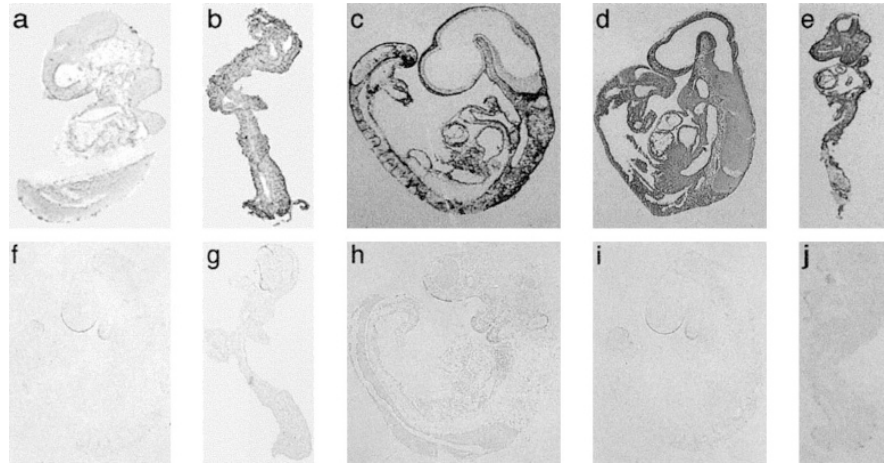

g
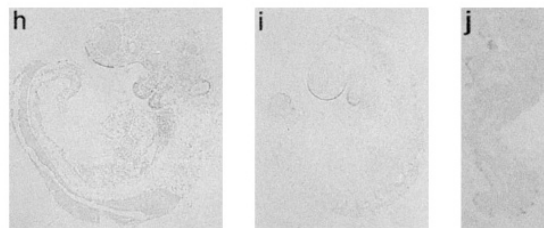

Figure 4. Immunohistochemistry of PKC $\beta-1$ in embryos. Distribution of PKC- $\beta 1$ in a d-10 embryo of a normal rat $(a)$, in a d-10 malformed embryo from a diabetic rat $(b)$, in a d-11 embryo of a normal rat $(c)$, in a d-11 nonmalformed embryo of a diabetic rat $(d)$, and in a d-11 malformed embryo of a diabetic rat $(e)$. The five last panels $(f-j)$ show a negative control for each group, i.e. an embryo processed for immunostaining with a blocking peptide added to the primary antibody.

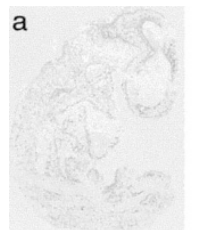

f

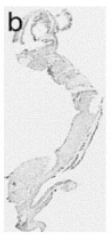

g
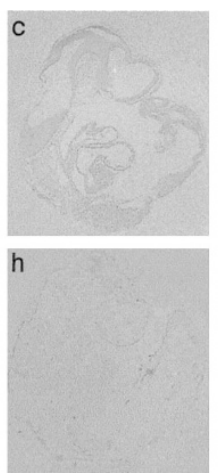
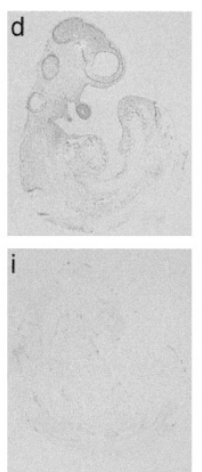

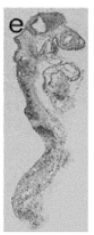

j
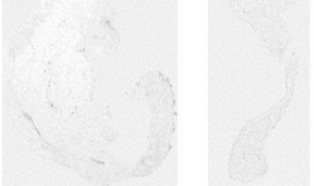

Figure 5. Immunohistochemistry of PKC $\beta-2$ in embryos. Distribution of PKC- $\beta 2$ in a d-10 embryo of a normal rat $(a)$, in a d-10 malformed embryo from a diabetic rat $(b)$, in a d-11 embryo of a normal rat $(c)$, in a d-11 nonmalformed embryo of a diabetic rat $(d)$, and in a d-11 malformed embryo of a diabetic rat $(e)$. The five last panels $(f-j)$ show a negative control for each group, i.e. an embryo processed for immunostaining with a blocking peptide added to the primary antibody.

(Fig. 4, $a-e$, and Fig. 5, $a-e$ ). As negative control we used the same staining procedure with a blocking peptide included, which effectively inhibited all specific staining (Fig. $4, f_{-j}$, and Fig. $5, f-j)$.

\section{DISCUSSION}

The major findings in the present study were the markers of increased activity of PKC- $\alpha$, PKC- $\beta 1$, PKC- $\gamma$, PKC- $\delta$, and $\mathrm{PKC}-\zeta$ in embryos of diabetic rats and the specific and superimposed increase in markers of PKC- $\gamma$ and PKC- $\delta$ activity in malformed embryos of diabetic rats. All of these changes were found on gestational d 10. In addition, we report increased immunohistochemical localization of PKC- $\beta 1$ and PKC- $\beta 2$ in malformed embryos of diabetic rats.

Our findings both resemble and differ with previous results. They support the view of an increased PKC activity in diabetes-exposed tissues but differ with earlier findings, inasmuch as the PKC activation in our hands was not constant but rather confined to a limited period of embryogenesis, mainly gestational d 10 .
Disturbed embryonic development in a diabetic environment has been investigated in relation to changes in PKC activity $(29,31)$. In a mouse model of diabetic embryopathy an association between exposure to a diabetic environment and enhanced embryonic PKC activity was recently reported (29). On the other hand, inhibition of PKC has been shown to cause malformations in rodent embryos $(30,31)$ and, furthermore, administration of a PKC inhibitor to embryos subjected to teratogenic glucose concentrations in vitro failed to diminish the disturbed embryonic development (31), thereby indicating the absolute requirement of a basal PKC activity for normal embryogenesis. Both high and low PKC activities have, therefore, been associated with disturbed embryogenesis in models of diabetic embryopathy. The stimulation of several PKC isoenzymes on gestational d 10 in the present study would support the notion of PKC activation as a component in the teratogenic process, or, alternatively, as an indicator of disturbed development in a diabetic environment.

The relation between a diabetic milieu and alterations in PKC activity is somewhat complex. Previous studies have identified one effect of increased ambient levels of glucose, a decreased uptake of inositol by the shared transport system (48). A decreased intracellular level of inositol would yield decreased amounts of the phosphoinositides PI, PIP, PIP 2 , and DAG (49), and a decreased activation of DAG-dependent isoforms of $\mathrm{PKC}(\alpha, \beta 1, \beta 2, \gamma, \delta, \epsilon, \eta, \theta)$. This inhibiting effect of a diabetic environment on PKC activity may, on the other hand, be counterbalanced by an increased availability of DAG resulting from another set of consequences of the diabetic state, namely an enhanced flux and accumulation of metabolites in the glycolytic pathway. This enhanced glycolytic flux may inhibit the activity of the glycolytic enzyme GAPDH via overproduction of reactive oxygen species in the mitochondria (50). The resulting inhibition of the glycolysis at the level of GAPDH would lead to accumulation of glycolytic metabolites upstream of this enzyme (51). The increased availability of glyceraldehyde would provide increased amount of the backbone of DAG and, hence, stimulate PKC activity. Which one of these opposite influences that is predominant may vary between different tissues and developmental times, indeed also between embryonic and adult tissues. In the present study, we found evidence of enhanced PKC activity on gestational d 10 but not on gestational d 11 in rat embryonic tissues exposed to a diabetic environment.

In the present study, we used the normalized densitometrically determined membrane-bound fraction of each PKC isoenzyme as a measure of the enzymatic activity of this enzyme. We used the ratio of immunoreactive membrane-bound PKC protein to immunoreactive cytosolic $\mathrm{PKC}$ protein $(\mathrm{m} / \mathrm{c}$ ratio) as a measure of the extent of membrane translocation of PKC isoenzyme within each experimental group

The association between structural defects in the embryo and enhanced activity of several PKC isoenzymes, found in the present study, is more enigmatic. If there is a causal relationship between these events, it may be inquired whether embryos that are damaged also develop a set of active PKC isoenzymes or whether PKC activation actually precedes and contributes to the embryonic dysmorphogenesis. Activation of PKC may 
therefore either be a consequence of embryonic maldevelopment or may be involved in the induction of the developmental disturbance. This issue has to be addressed in future studies; however, inasmuch as inhibition of PKC activity does not protect rat embryos from glucose-induced dysmorphogenesis in vitro (31), the notion of $\mathrm{PKC}$ activation as an indicator rather than a cause of embryonic maldevelopment has, at least so far, gained more support.

The mRNA levels of the seven isoforms of PKC were relatively constant regardless of gestational age or maternal metabolic condition. The developmental and physiologic consequences of the three changes recorded-i.e. increased mRNA levels of PKC- $\beta 1$ and PKC- $\zeta$ on gestational d 10 in embryos of diabetic rats and decreased mRNA levels of PKC- $\gamma$ on $\mathrm{d} 11$ in these embryos-are not evident. The changes in mRNA levels are roughly parallel to the changes in activity recorded for these three PKC isoenzymes; however, the majority of alterations in isoenzyme activity were not reflected in changes in gene expression. Therefore, it seems that the regulation of gene expression and the activity of the different PKC proteins are not identical.

With regard to the immunohistochemical demonstration of the PKC- $\beta 1$ and $\beta 2$ isoforms there were no clear differences in staining between the embryos from normal rats and the nonmalformed embryos of diabetic rats. However, the malformed embryos from diabetic rats showed a stronger immunostaining compared with the embryos of the other groups. This suggests an association between embryonic maldevelopment on one hand and enhanced tissue distribution/activity of these two PKC isoenzymes on the other.

In malformed d-10 embryos from diabetic rats, we found a pronounced increase in activity markers of two PKC isoforms, PKC- $\gamma$ and PKC- $\delta$. Whether this process is regulated at gene level is not apparent, the mRNA levels and the protein distribution of these two isoforms were not affected. This finding shows an association between embryonic maldevelopment and enhanced PKC- $\gamma$ and PKC- $\delta$ activity; however, the possibility of a causal relationship between these events requires further studies.

In the present study, we investigated the activity of seven isoforms of PKC in embryos on gestational d 10 and 11 . We found a general activation of five PKC isoenzymes (PKC- $\alpha$, PKC- $\beta 1$, PKC- $\gamma$, PKC- $\delta$, and PKC- $\zeta$ ) in embryos of diabetic rats on gestational $\mathrm{d} 10$. In addition, we found a superimposed activation of PKC- $\gamma$ and PKC- $\delta$ in malformed embryos of diabetic rats on gestational $\mathrm{d} 10$. This finding may suggest that diabetes provokes a general PKC activation in rodent embryos, as reported earlier (29), resembling the activation found in adult endothelial (52-54) and retinal cells $(55,56)$. However, this general PKC activation appears to be transient; we found unchanged or decreased PKC activities on gestational d 11 in embryos of diabetic rats compared with embryos of control rats. Taken together, the data of our study and other studies suggest an association between diabetic embryopathy and disturbed PKC activity. To determine whether and how these events are causally related will require further studies.
Acknowledgments. The authors thank Professor Ulf J. Eriksson for critical review of the manuscript and Thomas Backman, master of medicine/pharmaceutical sciences, for substantial initial support in the study.

\section{REFERENCES}

1. Kucera J 1971 Rate and type of congenital anomalies among offspring of diabetic women. J Reprod Med 7:61-70

2. Mills JL 1982 Malformations in infants of diabetic mothers. Teratology 25:385-394

3. Aberg A, Westbom L, Kallen B 2001 Congenital malformations among infants whose mothers had gestational diabetes or preexisting diabetes. Early Hum Dev 61:85-95

4. Queisser-Luft A, Stolz G, Wiesel A, Schlaefer K, Spranger J 2002 Malformations in newborn: results based on 30,940 infants and fetuses from the Mainz congenital birth defect monitoring system (1990-1998). Arch Gynecol Obstet 266:163-167

5. Becerra JE, Khoury MJ, Cordero JF, Erickson JD 1990 Diabetes mellitus during pregnancy and the risks for specific birth defects: a population-based case-control study. Pediatrics 85:1-9

6. Hawthorne G, Robson S, Ryall EA, Sen D, Roberts SH, Ward Platt MP 1997 Prospective population based survey of outcome of pregnancy in diabetic women: results of the Northern Diabetic Pregnancy Audit, 1994. BMJ 315:279-281

7. Penney GC, Mair G, Pearson DW 2003 Outcomes of pregnancies in women with type 1 diabetes in Scotland: a national population-based study. BJOG 110:315-318

8. Freinkel N, Metzger BE, Phelps RL, Simpson JL, Martin AO, Radvany R, Ober C, Dooley SL, Depp RO, Belton A 1986 Gestational diabetes mellitus: a syndrome with phenotypic and genotypic heterogeneity. Horm Metab Res 18:427-430

9. Mills JL, Knopp RH, Simpson JL, Jovanovic-Peterson L, Metzger BE, Holmes LB, Aarons JH, Brown Z, Reed GF, Bieber FR, Van Allen M, Holzman I, Ober C, Peterson CM, Withiam MJ, Duckles A, Mueller-Heubach E, Polk BF, National Institute of Child Health and Human Development Diabetes in Early Pregnancy Study Group 1988 Lack of relation of increased malformation rates in infants of diabetic mothers to glycemic control during organogenesis. N Engl J Med 318:671-676

10. Martínez-Frias ML 1994 Epidemiological analysis of outcomes of pregnancy in diabetic mothers: identification of the most characteristic and most frequent congenital anomalies. Am J Med Genet 51:108-113

11. Schaefer UM, Songster G, Xiang A, Berkowitz K, Buchanan TA, Kjos SL 1997 Congenital malformations in offspring of women with hyperglycemia first detected during pregnancy. Am J Obstet Gynecol 177:1165-1171

12. Brownlee M 2001 Biochemistry and molecular cell biology of diabetic complications. Nature 414:813-820

13. Sheetz MJ, King GL 2002 Molecular understanding of hyperglycemia's adverse effects for diabetic complications. JAMA 288:2579-2588

14. Cockroft DL, Coppola PT 1977 Teratogenic effect of excess glucose on head-fold rat embryos in culture. Teratology 16:141-146

15. Sadler TW 1980 Effects of maternal diabetes on early embryogenesis. II. Hyperglycemia-induced exencephaly. Teratology 21:349-356

16. Sadler TW, Hunter ES, Wynn RE, Phillips LS 1989 Evidence for multifactorial origin of diabetes-induced embryopathies. Diabetes 38:70-74

17. Menegola E, Broccia ML, Prati M, Giavini E 1999 Development of rat embryos cultured in serum from diabetic rats. Biol Neonate 75:65-72

18. Eriksson UJ, Borg LAH 1991 Protection by free oxygen radical scavenging enzymes against glucose-induced embryonic malformations in vitro. Diabetologia 34:325-331

19. Eriksson UJ, Borg LAH, Hagay Z, Groner Y 1993 Increased superoxide dismutase (SOD) activity in embryos of transgenic mice protects from the teratogenic effects of a diabetic environment. Diabetes 42(suppl 1):85A

20. Eriksson UJ, Naeser P, Brolin SE 1986 Increased accumulation of sorbitol in offspring of manifest diabetic rats. Diabetes 35:1356-1363

21. Hod M, Star S, Passonneau JV, Unterman TG, Freinkel N 1986 Effect of hyperglycemia on sorbitol and myo-inositol content of cultured rat conceptus: failure of aldose reductase inhibitors to modify myo-inositol depletion and dysmorphogenesis. Biochem Biophys Res Commun 140:974-980

22. Hashimoto M, Akazawa S, Akazawa M, Akashi M, Yamamoto H, Maeda Y, Yamaguchi Y, Yamasaki H, Tahara D, Nakanishi T, Nagataki S 1990 Effects of hyperglycaemia on sorbitol and myo-inositol contents of cultured embryos: treatment with aldose reductase inhibitor and myo-inositol supplementation. Diabetologia 33:597-602

23. Goldman AS, Baker L, Piddington R, Marx B, Herold R, Egler J 1985 Hyperglycemia-induced teratogenesis is mediated by a functional deficiency of arachidonic acid. Proc Natl Acad Sci U S A 82:8227-8231

24. Baker L, Piddington R, Goldman A, Egler J, Moehring J 1990 Myo-inositol and prostaglandins reverse the glucose inhibition of neural tube fusion in cultured mouse embryos. Diabetologia 33:593-596

25. Piddington R, Joyce J, Dhanasekaran P, Baker L 1996 Diabetes mellitus affects prostaglandin E2 levels in mouse embryos during neurulation. Diabetologia 39:915920

26. Wentzel P, Welsh N, Eriksson UJ 1999 Developmental damage, increased lipid peroxidation, diminished cyclooxygenase-2 gene expression, and lowered PGE2 levels in rat embryos exposed to a diabetic environment. Diabetes 48:813-820

27. Koya D, King GL 1998 Protein kinase C activation and the development of diabetic complications. Diabetes 47:859-866

28. Kamiya H, Nakamura J, Hamada Y, Nakashima E, Naruse K, Kato K, Yasuda Y, Hotta N 2003 Polyol pathway and protein kinase C activity of rat Schwannoma cells. Diabetes Metab Res Rev 19:131-139 
29. Hiramatsu Y, Sekiguchi N, Hayashi M, Isshiki K, Yokota T, King GL, Loeken MR 2002 Diacylglycerol production and protein kinase $\mathrm{C}$ activity are increased in a mouse model of diabetic embryopathy. Diabetes 51:2804-2810

30. Ward KW, Rogers EH, Hunter ES 1998 Dysmorphogenic effects of a specific protein kinase $\mathrm{C}$ inhibitor during neurulation. Reprod Toxicol 12:525-534

31. Wentzel P, Wentzel CR, Gareskog MB, Eriksson UJ 2001 Induction of embryonic dysmorphogenesis by high glucose concentration, disturbed inositol metabolism, and inhibited protein kinase C activity. Teratology 63:193-201

32. Buchner K 2000 The role of protein kinase $\mathrm{C}$ in the regulation of cell growth and in signalling to the cell nucleus. J Cancer Res Clin Oncol 126:1-11

33. Blackshear PJ, Lai WS, Tuttle JS, Stumpo DJ, Kennington E, Nairn AC, Sulik KK 1996 Developmental expression of MARCKS and protein kinase $\mathrm{C}$ in mice in relation to the exencephaly resulting from MARCKS deficiency. Brain Res Dev Brain Res 96:62-75

34. Oehrlein SA, Maelicke A, Herget T 1998 Expression of protein kinase C gene family members is temporally and spatially regulated during neural development in vitro. Eur J Cell Biol 77:323-337

35. Nishizuka Y 1986 Studies and perspectives of protein kinase C. Science 233:305-312

36. Raz T, Eliyahu E, Yesodi V, Shalgi R 1998 Profile of protein kinase C isozymes and their possible role in mammalian egg activation. FEBS Lett 431:415-418

37. Gil C, Chaib-Oukadour I, Blasi J, Aguilera J 2001 HC fragment (C-terminal portion of the heavy chain) of tetanus toxin activates protein kinase $\mathrm{C}$ isoforms and phosphoproteins involved in signal transduction. Biochem J 356:97-103

38. Wu CH, Chang CH, Lin HC, Chen CM, Lin CH, Lee HM 2003 Role of protein kinase $\mathrm{C}$ in BSA-AGE-mediated inducible nitric oxide synthase expression in RAW 264.7 macrophages. Biochem Pharmacol 66:203-212

39. Kinoshita N, Iioka H, Miyakoshi A, Ueno N 2003 PKC delta is essential for Dishevelled function in a noncanonical Wnt pathway that regulates Xenopus convergent extension movements. Genes Dev 17:1663-1676

40. Akita Y 2002 Protein kinase C-epsilon (PKC-epsilon): its unique structure and function. J Biochem (Tokyo) 132:847-852

41. Koponen S, Kurkinen K, Akerman KE, Mochly-Rosen D, Chan PH, Koistinaho J 2003 Prevention of NDA-induced death of cortical neurons by inhibition of protein kinase Czeta. J Neurochem 86:442-450

42. Alcazar O, Qiu-yue Z, Gine E, Tamarit-Rodriguez J 1997 Stimulation of islet protein kinase $\mathrm{C}$ translocation by palmitate requires metabolism of the fatty acid. Diabetes 46:1153-1158

43. Ceolotto G, Gallo A, Miola M, Sartori M, Trevisan R, Del Prato S, Semplicini A, Avogaro A 1999 Protein kinase C activity is acutely regulated by plasma glucose concentration in human monocytes in vivo. Diabetes 48:1316-1322
44. Lehtihet M, Welsh N, Berggren PO, Cook GA, Sjoholm A 2003 Glibenclamide inhibits islet carnitine palmitoyltransferase 1 activity, leading to PKC-dependent insulin exocytosis. Am J Physiol 285:E438-E446

45. Eriksson UJ, Dahlstrom E, Larsson KS, Hellerstrom C 1982 Increased incidence of congenital malformations in the offspring of diabetic rats and their prevention by maternal insulin therapy. Diabetes 31:1-6

46. Eriksson UJ 1988 Importance of genetic predisposition and maternal environment for the occurrence of congenital malformations in offspring of diabetic rats. Teratology 37:365-374

47. Lowry OH, Rosebrough. NJ, Farr AL, Randall RJ 1951 Protein measurement with the Folin phenol reagent. J Biol Chem 193:265-275

48. Weigensberg MJ, Garcia-Palmer F-J, Freinkel N 1990 Uptake of myo-inositol by early-somite rat conceptus. Transport kinetics and effects of hyperglycemia. Diabetes 39:575-582

49. Strieleman PJ, Connors MA, Metzger BE 1992 Phosphoinositide metabolism in the developing conceptus. Effects of hyperglycemia and scyllo-inositol in rat embryo culture. Diabetes 41:989-997

50. Wentzel P, Ejdesjo A, Eriksson UJ 2003 Maternal diabetes in vivo and high glucose in vitro diminish GAPDH activity in rat embryos. Diabetes 52:1222-1228

51. Nishikawa T, Edelstein D, Du XL, Yamagishi S, Matsumura T, Kaneda Y, Yorek MA, Beebe D, Oates PJ, Hammes HP, Giardino I, Brownlee M 2000 Normalizing mitochondrial superoxide production blocks three pathways of hyperglycaemic damage. Nature 404:787-790

52. Ishii H, Koya D, King GL 1998 Protein kinase C activation and its role in the development of vascular complications in diabetes mellitus. J Mol Med 76:21-31

53. Meier M, King GL 2000 Protein kinase C activation and its pharmacological inhibition in vascular disease. Vasc Med 5:173-185

54. Way KJ, Katai N, King GL 2001 Protein kinase C and the development of diabetic vascular complications. Diabet Med 18:945-959

55. Yokota T, Ma RC, Park JY, Isshiki K, Sotiropoulos KB, Rauniyar RK, Bornfeldt KE King GL 2003 Role of protein kinase C on the expression of platelet-derived growth factor and endothelin-1 in the retina of diabetic rats and cultured retinal capillary pericytes. Diabetes 52:838-845

56. Hammes HP, Du X, Edelstein D, Taguchi T, Matsumura T, Ju Q, Lin J, Bierhaus A, Nawroth P, Hannak D, Neumaier M, Bergfeld R, Giardino I, Brownlee M 2003 Benfotiamine blocks three major pathways of hyperglycemic damage and prevents experimental diabetic retinopathy. Nat Med 9:294-299 